3. French Alan, and Gareth Smith. «Measuring Political Brand Equity: A Consumer Oriented Approach.» European Journal of Marketing, 2010. P. 460-477.

4. Kruglanski, A. W., and E. P. Thompson. «Persuasion by A Single Route: A View from the Unimodel», 1999. P. 83-109.

5. Lewandowsky, S., K. H. Ullrich, C. M. Ecker. «Misinformation and Its Correction: Continued Influence and Successful Debiasing.» Psychological Science in the Public Interest, 2012. P. 106-131.

6. Matsa Katerina Eva and Kristine Lu, «10 Facts about the Changing Digital News Landscape,» Pew Research Center, 14 September 2016. http://www.pewresearch.org/fact -tank/2016/09/14/facts-about-the-changingdigital-news-landscape/.

DOI https://doi.org/10.30525/978-9934-26-039-1-55

\title{
GERMANIC NUMERALS IN THE LIGHT OF LINGUOSYNERGETICS (ON THE MATERIAL OF DER RING`'BY HEINRICH WITTENWILLER)
}

\author{
Iarmolovych G. Yu. \\ Ph.D. Student at the Department of German Philology of the Faculty \\ of Romance and Germanic Philology \\ Odesa I. I. Mechnikov National University \\ Odesa, Ukraine
}

Numerals have been and still are a fruitful object of study in various fields, linguistics included. The immediate aim of this abstract is to outline the state of the system of numerals in the Middle High German language based on examples from medieval texts. It should be kept in mind that given examples only partially illustrate the dissertation research conducted by the author with the aim of connecting mathematical thinking and language development from the point of view of a self-organizing system.

Much has been written on the subject of the formation and development of numerals in Germanic languages from different perspectives. The theoretical basis of the study is built on the work of general linguists researching roots of the human language (Salmons, Renfrew, Gamkrelidze, Ivanov), philosophers (German, Arshinov, Dombrovan), germanists (Levicki, Kolotilova, Mallory, Taranets), ethnolinguists (Alexejev, Frank, Frolov, Kabo) and others. 
As research material, I have chosen a satirical didactic poem by Heinrich Wittenwiler, the Ring, which is perfectly placed between philological interest and reader-friendliness. With regard to this text, Horst Brunner [1, p.493] speaks of a «comic-didactic epos» and a «work sui generis», a unique work. Bernhard Sowinski [6, p. 133] calls it an «epic-didactic mixed poem», and Walter Haug [4, p. 171], elevates it to the «last significant Middle High German novel».

The text of Heinrich Wittenwiler's Ring has survived only in a single manuscript. The carefully crafted copy, believed by some to may even have been created in the author's immediate environment, is a mix of AlemannicBavarian language and is dated around 1410 . For pragmatic reasons, this study uses the new edition with commentary and translation by Werner Röcke [7, p. 7-17], which also includes a reprint of the text according to Edmund Wiessner. It is particularly valuable that this text was produced as a result of «research-based learning». The translation of individual words, sentences, sequences of sentences and linguistic images was discussed in detail and then the most suitable variant was agreed upon.

According to documents of the later 15th century, the author of the text belonged to the highest class of officials in the vicinity of the bishop's court in Constance. He was of noble origin and studied law in Bologna. By skilfully applying poetic, didactic and encyclopaedic knowledge, Heinrich Wittenwiller, according to Röcke, reached far beyond the intellectual capabilities of his contemporaries and surpassed them [7, p. 9].

The text comprises 9699 stanzas and is divided into three parts. The three parts of courtship, marriage and war gradually show the reader how the main character, the happy farmer Bertchtold, becomes a recluse in the Black Forest as a result of a tragicomic chain of misfortune. The language of the manuscript is classified as Allemanic-Bavarian on the basisof several peculiarities. According to Kranzmayer and Weinhold [5, p. 23], such spelling-related (Bavarian) peculiarities include the « $w$ » spelling for $b$, the assimilation $m>n$, the nasal fading in the internal and external sounds, occasional «Bavarian» diphthongs $(u \circ, \imath$ ) for mhd. $u /<$ or $i$; ending drop (especially in the 1 st pers. pl. Ind. and Conj.Prs. and 3rd pers. pl. Ind. and Conj. Prt.); the depiction of Germanic «k» in the initial sound as «ch» and the transformation of «p» sounds to $\langle f\rangle$ or $\langle p f\rangle$. Not all of the above spelling peculiarities concern numerals found in the text.

Thanks to its form, the novel offers a variety of numerals and words derived from them. The latter include nouns, verbs, adjectives, indefinite pronouns, adverbs and prepositions. In total, there are 1462 units containing 18 
roots of numerals, which is $2.5 \%$ percent in relation to the total number (57855).

The numeral «one» offers the most extensive number of examples and performs three main functions - numeral (meaning one, only, alone, solely), indefinite pronoun (meaning any, a certain) and indefinite article. Depending on the accompanying word, «one» inflects either strongly or weakly. The compounds with «one» such as «dehein» - «any, a certain one», and «nehein» - «none» inflect like a strong adjective.

The number words «two» and «three», as well as «one», are present in three genders and are declinable in Middle High German. The inflection scheme of these numerals has been determined by many linguists since Karl Lachmann and is almost completely described in this research material. The following forms occur here: zwei zwai zwier zwiu zwene zwo, drie dri drei, dru.

The other cardinalia, from «four» to «nineteen», generally occur uninflected, except in post position or when used as substantives. For example: pre-positioned - «da waren vier und fumfzech fursten riche» post-positioned, and already inflected - «Der edele und der ziere, den heten bestanden edeler rekchen viere».

The basic numbers zweinzech, drizzig, vierzech, fumfzech, fumfzehen, ahzehen are etymologically compound words with the second component -ziczig-zich-zech-zick-zehen- 'tens'. The linguist Sonderreger points out that such indeclinable formations have no inflection.

The «hundred» and «thousand» appear relatively often in the text, mostly with an accompanying numeral such as «Mir und minen geverten ich vnd myn geuerten wartent ahzehen tousent man», "Sehs und zweinzech tosent rekchen ich hie han», "niun hundert man dannoch erslagen», but sometimes still in compounds with another numeral in the stem «Drutusent helde bringen». According to Helmut de Boor, «tusend» is a feminine noun and can be declined [3, p. 706].

The ordinalia also occur frequently in the text, especially the exceptions not formed from cardinalia: the superlative form «first», which is often used here as an adverb and means, according to Chemodanov «the very first and the one started» or - «first», and an inflected pronominal adjective «ander anderen anders» $[2$, p. 266]. The corresponding New High German ordinal «second» has existed only since the 16th century and does not occur even in the latest copies of the manuscript. The other ordinalia are formed from the cardinalia, such as «Der dritte rekche maere», «Daz fumfte sei der chekche», «Daz sibende si her Baltram». 
The indefinite number words build an independent group. An opposition vil-vielen-vieln - wenig-wenich occurs in 412 examples. Although they do not give information about the concrete number, they convey a sense of quantity and matter as a concept.

As a result of this research, the following can be concluded.

1) The cardinal numbers show a very staggered inflection in Middle High German, which can be seen very well from the rich supply of numerals in the text under study.

2) The ordinalia also occur frequently in this text thanks to the enumeration of the knights. virde-vierde, sechste - sehste, niunte - neunte.

3) The Bavarian spelling peculiarities of some numeral words reflect the peculiar East Bavarian dialect formation in which the manuscript was written. Apart from the Bavarian diphthong in several numeral words and nasal fading in the numeral word «fumf», the proclitic connection of ze-zuo with the following numeral word is typical for this time (zebeide).

4) When analysing the manuscript, I came across temporal and spatial differences. One encounters, among other things:

- different graphs for the same phonemes, ein-ain, zwei-zwai, dri-drie, virde-vierde, niun-neun, kein-kain, vil-vielen;

- inconsistent umlaut designation einlef - aindliff - eilff, zwei-zwozwene-zwiu;

- functionless multiple consonance viertzigk, dreizzich, zwaintzig;

Number words are almost the most enduring elements of the IndoEuropean language system, note Indo-European language origin theorists. In the search for the origin of the Indo-European language, in the systematisation of languages and in comparative studies, number words become valuable objects of research. My dissertation directly profits from their stability, building a rich reliable ground for further review of the appearance, development and self-organisation of numerals from the perspective of linguosynergetics.

\section{References:}

1. Brunner H. Geschichte der deutschen Literatur des Mittelalters und der Frühen Neuzeit im Überblic. 2019. 536 p.

2. Chemodanov N. S. A german language history reader. Moskow, 1978. $288 \mathrm{p}$.

3. de Boor H. Über dreisilbige und zweisilbige Komposita und Derivata im Nibelungenlied, bei Gottfried und Hartmann. Ein Beitrag zur Frage des Verhältnisses von Sprachrhythmus und Versrhythmus. Sonderheft (Festschrift Hans Eggers), 1972. P. 703-725. 
4. Haug W. Von der Idealität des arthurischen Festes zur apokalyptischen Orgie in Wittenwilers ,Ring'. Poetik und Hermeneutik. 1989. № 14. P. 157-179.

5. Lienert E., Wolter D.. Die Rabenschlacht. Tübingen: Max Niemeyer, 2005. 314 p.

6. Sowinski B. Kompositions-und Gattungsfragen zu Heinrich Wittenwilers ,Ring'. Sprachgeschichte als Textsortengeschichte. Festschrift zum 65. Geburtstag von Gotthard Lerchner. 2000. P. 133-146.

7. Wittenwiller H. Der Ring. Berlin: W. de Gruyter, 2012. 538 p.

DOI https://doi.org/10.30525/978-9934-26-039-1-56

\title{
ЛЕКСИКОГРАФІЧНЕ ВІДОБРАЖЕННЯ КОНЦЕПТУ «КРАСА» В АНГЛІЙСЬКИХ ФРАЗЕОЛОГІЗМАХ
}

\author{
Ярова Л. О. \\ кандидат педагогічних наук, \\ дочент кафедри перекладу, прикладної та загальної лінгвістики \\ Центральноукраӥнського державного педагогічного університету \\ імені Володимира Винниченка \\ Поліщук Г. В. \\ кандидат філологічних наук, \\ дочент кафедри англійської мови та методики ї̈ викладання \\ Центральноукраӥнського державного педагогічного університету \\ імені Володимира Винниченка \\ м. Кропивницький, Украӥна
}

Протягом останніх десятиліть в лінгвістиці спостерігається перехід на антропоцентричну парадигму дослідження, де в центрі уваги дослідників перебуває комплекс проблем, пов'язаних із взаємодією людини і мови, що зумовили зростання інтересу до концепта, який пов'язаний із вмістом суб'єктивного ментального світу людини та ментальної свідомості нації в цілому. Отже, вивчення концептів дозволяє виявити національнокультурну специфіку мовної картини світу тієї чи іншої мовної спільноти, описати менталітет носіїв мови за допомогою аналізу мовних засобів, що якнайкраще відображено у фразеологізмах, оскільки в них не лише закарбована вікова народна мудрість, ціннісна картина світу нації, але й в афористичній формі міститься сума активних і пасивних знань 216 